\title{
Project Finance in the Energy Industry: New Debt-based Financing Models
}

\author{
Enzo Scannella \\ Department of Economics, Business and Finance, University of Palermo \\ Viale delle Scienze, cap. 90128 - Palermo, Italy \\ Tel: 39-091-2389-5305 E-mail: enzo.scannella@unipa.it
}

Received: October 13, 2011

Accepted: December 19, $2011 \quad$ Published: February 1, 2012

doi:10.5539/ibr.v5n2p83

URL: http://dx.doi.org/10.5539/ibr.v5n2p83

\begin{abstract}
The paper aims to examine the development of new financing models for project finance to attract private investors to finance large European energy infrastructure projects. In particular, the paper investigates the uniqueness of the project finance as a rapidly growing field in finance, the financial characteristics of the project bond market as one of the vehicles for funding energy projects, and the role of the credit support provided by the European Investment Bank and the European Union to promote the bond-based financing schemes. The paper is organized as follows. Section 1 provides a general description of project finance. Section 2 identifies the economic reasons for using project finance and assesses the role of the project bond market to fund project finance in the energy industry. Section 3 evaluates the proposed financial support from the European Investment Bank and the European Union to boost the European project bond market. Final sections discuss policy implications and conclude.
\end{abstract}

Keywords: Project finance, Energy industry, Project bond, Credit enhancement

\section{Introduction}

Many studies have highlighted the development of energy projects is fundamental for Europe's competitiveness, productivity, long term growth, modernization, and energy supply sustainability and efficiency. Long-term investment is a vital driver for a sustainable growth, employment and financial stability. Large energy infrastructure projects require decades of revenues to amortise the high upfront investment and long-term financing schemes. It requires a long-term vision (policy-makers, regulation and financial institutions) rather than a focus on short-term results, especially on investments with significant positive externalities for growth (Khan \& Parra, 2003).

According to the European Commission, by 2020 there will be considerable investment needs in European energy, transport and information and communication technology (ICT) infrastructures. The Commission estimates that by 2020 the investment needs for energy, transport and ICT infrastructures will amount to 2 trillion Euros.

The debate concerning the funding of long-term investments has grown considerably in recent years in Europe. Due to limited bank lending capacity, long-term bank lending could not be sufficient to finance energy projects in Europe. In addition, due to high public debt European countries are not able to finance large projects with public capital. Consequently, it is necessary to attract an increasing amount of private capital to finance long-term investments. In order to do so innovative financing models and new financial instruments are needed.

To increase investment in projects that promote structural change and sustainable growth, the European Commission launched the stakeholders' consultation (Europe 2020 Project Bond Initiative) on 28 February 2011. The principal idea behind the Europe 2020 Project Bond Initiative is to provide EU support to project companies issuing bonds to finance large-scale infrastructure projects. This initiative recognizes that capital markets are an alternative source of funding for energy projects. It is supported by the Commission and European Investment Bank (EIB) in order to build on existing experience with joint EU-EIB instruments and EIB's experience in EU infrastructure financing.

Project finance has proven to be a useful financing technique throughout the world and across many industry sectors (Buljevich \& Park, 1999; Esty, 2004b; Fabozzi \& Nevitt, 2000; Gatti, 2008). Project finance has long been used to fund large-scale energy projects (such as power generation facilities, oil and natural gas pipelines, electric utilities, chemical plants, water and waste water treatment facilities, renewable energy and green technologies, etc.) both in the developed world as well as developing countries. The percentage of capital investment worldwide that is financed on a project basis is likely to increase in the future. 
Project finance may be defined as the raising of funds to finance an economically separable capital investment project in which the providers of the funds look to the cash flows from the project as the source of funds to service their loans and provide a return on equity capital invested in the project. The basic characteristic of project finance is that lenders loan money for the development of a project solely based on the specific project's risks and future cash flows. This highlights a key feature of project finance due to the capacity to generate cash flows to ensure the repayment of loans and adequate returns on equity capital. A revenue stream from the project large enough is a prerequisite for project financing.

Project finance should be distinguished from conventional direct finance. In the direct finance model, lenders look to the firm's entire asset portfolio to generate the cash flow to service their loans. In the project finance model, lenders look to the single project as a distinct legal entity. The main difference between corporate finance and project finance is that the assets are financed as stand-alone entities rather than as part of a corporate balance sheet. The project must be able to generate sufficient funds to cover all operating costs and debt service while still providing an acceptable return on the equity invested in the project. Project finance depends on a detailed evaluation of a project's construction, operating and revenue risks, and their allocation between investors, lenders, and other parties through contractual and other arrangements.

The development of new financing models for project finance is likely to attract private sector investor to finance large European energy infrastructure projects in a difficult public financial context. Innovative financing techniques are offering more financing options in the energy industry. The project bond could be a useful long-term financial instrument to mobilise the necessary financing to meet EU's strategic energy infrastructure needs. Nevertheless, it will depend on the exact characteristics of the projects and the corresponding project bonds.

\section{The Financial Structure of Project Finance in the Energy Industry: Bank Loan Market vs. Bond Market}

Project finance is a useful technique for financing large projects that can be organized as a stand alone company. It is an appropriate method of long-term financing for capital-intensive industries where the investment financed has a relatively predictable cash flow. A special purpose legal entity (project company) is a purely private company in which private investors bear the entire investment risk or a public-private company in which public and private partners share the investment risk (public-private partnerships). Project finance involves both an investment decision and a financing decision. One of the key structural features that characterize project finance is the distinction between the asset (the project) and the financing structure. The project company lies at the center of all the contractual and financial relationships in project finance scheme. Project financing arrangements involve many contractual relationships among multiple parties. Project finance builds on the set of numerous contracts that define the business and financial relationships:

- Supply contracts: they ensure adequate sources of supply;

- Construction contracts: they define the terms on which a qualified contractor will build the project facilities;

- Financial contracts: to raise debt and equity to finance the project;

- Operating contracts: to govern the day-to-day operation of the project company.

Project finance is an innovative model of financing projects. Its unique structural attributes provide valuable insights to identify the primary motivations for using project finance:

\section{- Cash flow-based financing}

financing decisions are based on the cash flows that the project is expected to generate;

\section{- Off-balance-sheet financing}

The project finance allows investors to keep debt off the balance sheet. It involves the use of a special purpose vehicle (SPV) to isolate assets in a separate entity and fund a project with only limited recourse to the assets of external investors;

\section{- High leverage financing}

For equity investors, the appeal of project finance is that it can maximize equity returns. In project finance it is possible to achieve much higher leverage ratios than sponsors could otherwise sustain on their own balance sheets;

\section{- Large project financing}

Investors make use of project finance to fund projects that may be too large for one investor to undertake on its corporate balance sheet; 
On average project finance loans have a longer term than corporate loans.

The growing use of project finance challenges the Modigliani and Miller's "irrelevance proposition", the idea that corporate financing decisions do not affect firm value under certain conditions (Esty, 2004a). Project finance is an innovative financing vehicle and it offers an important example to illustrate that financing and investment decisions are not separable and independent activities. Financing structure matters. They are value relevant and financing decisions affect investment decisions.

The project finance has two sources of funds: debt and equity. Debt is provides by lenders and equity is provided by investors in the project. The traditional debt-based financing model is the bank loan. It is the traditional way to raise long-term funding for long-term projects. Debt capital is provided by large financial institutions (traditionally commercial banks), including international banks. Banks are the largest providers of debt project finance. It shows the importance of banking relationships in the project finance market. The need to raise capital, typically from banks, makes it significantly more difficult to finance projects with negative net-present-value. Convincing bankers to provide a large portion of the capital is an important constraint. Banks specifically focus on the ability of the project to make loan repayments. Banks may finance project companies directly or indirectly, through participation in syndicated loans. The latter are originally arranged and underwritten by large banks and then usually offered to domestic banks as sub-underwriters. Generally, large deals tend to be syndicated (Kleimeier \& Megginson, 2000). In large projects, several banks are usually involved as financial advisers and lead managers, who will underwrite the debt and place it in the capital market. They normally divide responsibilities for various aspects of the project finance structure. Project bank loans have been concentrated in USA, Europe, Middle East, and Africa, where most of the large projects have been located. They have also been concentrated in the power industries, oil and gas, and the transportation industry, where most of the large projects have taken place.

Equity is the second source of capital to finance large projects. Typically the project sponsors provide the greatest proportion of initial project equity. Outside equity investors, usually financial institutions (commercial banks, investment funds specializing in project finance equity, equity vehicles), may invest equity in a project. Venture capital and private equity investors also serve as attractive sources for capital raising, as an increasing number of funds are investing in renewable energy and green technologies to diversify their portfolios. The size of cash distribution to equity investors is not specified contractually. It depends on the profitability of the project and the expected residual value of the project. Equity investors receive cash distribution after paying debt service. A reasonable return on equity investment is necessary to involve equity investors in the project. The return required by equity investors also varies depending on when they come into the project. Any project has different levels of risk over time and investors get into projects at different stages and with different investment strategies. Equity investors have a level of return on equity above which an investment is acceptable, and below which it is not. It depends on the cost of capital, the type of the project, the technology, the risks, the security package, etc.

The mix of debt and equity funding sources has changed during the last years as the capital market for project bonds has grown. A new debt-based financing model is the issue of bonds. Private (or public-private) project companies issue bonds (project bonds) on capital markets to finance projects in the energy industry. Project bonds are private debt. They are issued by project companies and not by European member states or the EU. Issuing bonds would expand the access to a broader capital market and long-term funding. The investor base can be expanded from bank loans to capital market by project bonds. Bond-based financing model aims mainly at the non-banking market and takes the form of a tradable financial instrument. Project bonds are issued with the intervention of investment banks. Project bonds may be public issues (they are placed with bond investors through the stock exchange) or private placement (they are placed with a limited number of bond investors). The evolution of project bonds is benchmarked against the more established fixed income markets in terms of pricing as well as legal structures and covenant provisions (Dailami and Hauswald, 2003; John \& John, 1991).

The typical project has $70 \%$ to $75 \%$ debt and $25 \%$ to $30 \%$ equity. Banks provide $2 / 3$ of the debt, and the bonds or multilateral development agencies provide the rest of the debt. Annual project bond issuance has grown steadily since 1992. The project bond market is concentrated in United States. It accounts for more than half of the global issuance of project bond in the world. The investment banks most active in placing project bonds are also mainly US-based. From the industry sector point of view, the project bond market is concentrated in the power projects, oil and gas projects, and infrastructure concessions.

There is no universal rule for choosing specific financing options in the project finance. Various factors affect the choice of using bank loans or project bonds (or a combination of the two) for financing projects. Bank loans can be provided to any credit worthy market, but bonds may be available only in certain markets (typically developed markets). Bonds generally offer a longer term of repayment compared to bank loans. Bank loans and bonds 
generally offer fixed rates of interest. In some markets it is possible to issue bonds with the interest rate linked to the rate of inflation, if the project's revenues are linked to inflation. On the contrary, inflation-linked bank loans may be not available. Bank loans tend to maintain long-term policies towards project, while bonds can be more affected by investors' short-term attitude. Bank loans keep confidentiality in lending relationship, while bond markets need transparency. The terms of the project may have to be published in a bond prospectus. Banks loans imply low disclosure requirements, while bonds need public listing and high disclosure requirements. Bond investors have to face a higher level of information asymmetry than banks. In relationship lending banks may impose tight controls on the project company and do an effective monitoring of the credit positions. Bank loans may have a more flexible financing structure than project bonds (in terms of flexible repayment schedule, interest rate based on the performance of the project, flexible cash retention requirements, less restrictive covenants, etc.) (note 1). Bank loans are quick to deliver, while bonds need to involve third parties. If the project gets into difficulty, negotiations with banks could be kept confidential, while negotiations with bond holders may be publicized and less flexible. To refinance debt capital is easy for bank debt, but it is difficult for bonds. Bond-based financing methods imply higher transaction costs than bank loans.

Several factors influence the breadth of the project bond market for financing a project in the energy industry:

\section{a. Project Eligibility for the Bond Market}

An important financial characteristic of a suitable project is stable and strong cash flows. There is uncertainty as to the expected cash flows, which makes the investment risky. This is particularly evident in the energy industry where large projects are usually risky because of their size, the application of innovative production technologies, the amount of capital, the complex contractual relationships among various parties, the required financial and legal expertise and assistance. Projects usually undergo two main phases (construction and operation) characterised by quite different risks and cash flows. Most of the capital expenditures are typically concentrated in the initial construction phase, and most of the revenues are concentrated in the operation phase.

Investors will buy project bonds if projects are based on a sustainable financing model. Long-term lenders look solely to the project's cash flow for their repayment. A project cannot be financed on a project basis unless it is expected to be profitable. Investment decisions are influenced by the attractiveness of the rate of return offered by a project in relation to the expected rate of return of other projects and alternative comparable investments. Lenders make lending decisions based on their estimation of both the risks and returns of a project. The analysis involves assessing each type of risk and the means to mitigate its impact on the project. Assessing the returns involves verifying the cost and revenue projections. The higher the expected risk associated with a project, the higher the amount of equity the lenders will require in a project. In other words, the financing structure of the project reflects the characteristics of the assets and the contractual agreements (in terms of cash flows) from input suppliers to output buyers. Consequently, projects with long-term maturities and low risks are very suitable for debt capital markets. On the contrary, high risky projects are not that suitable.

The economic viability of a project is determined by the discounted cash flow analysis. It takes into account the timing of the cash inflows and outflows. Projecting the cash outflows and inflows is a critical part of the analysis. The outflows and inflows can be easy or really difficult to predict. It depends on the existence of purchase agreements that define contractually the price for each input and output, the price stability and the purchasing power of the currency, the complexity and innovative technology that is involved during the construction and operation period, the production capacity of the project, the riskiness of the project, and so on. The assumptions to estimate the project's cash flows are a crucial factor for the credibility and meaningfulness of project's financial statements. The cash flow projections indicate the expected profitability of the project and the expected cash flows that will be allocated among the providers of capital (debt and equity). This explains why lenders and equity investors are particularly interested in knowing the cash flow projection assumptions. An adequate financial model is an essential tool for financial evaluation of the project (Wynant, 1980).

\section{b. Credit Standing of the Project Entity}

The credit standing of the project bonds is a crucial factor for the success of the bond market. The rating is important for bond issuers because facilitate borrowers' access to global capital markets. The ability of certain investors to buy project bonds will be affected by the rating assigned the project bonds by the major rating agencies. It is important for bond investors because it offers a perspective on credit risk anchored on complex methodologies for risk analysis, and a well-understood categorisation of credit quality across debt sectors and regions. Bond investors are not directly involved in the due-diligence process and project evaluation to the extent that bank lenders, investment banks and financial advisers do, and rely on the rating issued by rating agencies. The rating of the project bonds aims to fill up an information gap (information asymmetry) between informed-insider players and 
uninformed-outsider players in the project finance structure. Project finance is affected by an incomplete information market where bond issuers (project companies) have information that investors do not have (Myers and Majluf, 1984). The rating provides a measure of project bonds' default risk. If project bonds are not rated, investors may make very conservative assumptions about the default risk involved in the project and demand a higher interest rate. The credit standing of the project bonds affects the rate of interest lenders are willing to accept. In addition, most institutional investors, who represent the potential source of long-term funds for a project financing, invest in securities that are rated "investment-grade". This is due to corporate investment policy, risk management guidelines, or regulation.

The rating agencies can translate the available financial information into an assessment of the sponsor's credit risk exposure related to the project finance. Investors can incorporate their assessments into the prices they are willing to pay for each sponsor's outstanding securities. Rating agencies help control principal-agent conflicts because they review the economics of the project, review the contracts, and assess the appropriateness of the project's capital structure. Rating agencies also review the credit standing of the project bonds. However, the complexity of the credit risk analysis increases with the complexity of security packages involved in project financing.

\section{c. Project Financial Leverage}

The project company uses the revenues to repay the debt and equity capital. The project company has to match the value of long-dated assets with its long-dated liabilities. Lenders require sufficient equity to make the project creditworthy. In finance theory, an equity investor in a firm with high financial leverage would expect a higher return than one in a firm with low leverage. However, in project finance it is different, since its high leverage does not imply high risk (Beidleman, Fletcher, \& Veshosky, 1990; Yescombe, 2002). The project company can achieve high financial leverage ratios (debt-to-assets). Project finance is usually designed to achieve high initial financial leverage. Fabozzi \& Nevitt (2000) claim that, "project financing can sometimes be used to improve the return on the capital invested in a project by leveraging the investment to a greater extent than would be possible in a straight commercial financing of the project." A high level of debt is the essence of project finance. However, the projects do not maintain the same leverage ratios throughout the life of the project. As a project starts to generate positive operating cash flow, the loan covenants may require that project cash be used to reduce debt. Esty $(2002,2003)$ recognises, however, that higher leverage increases expected equity returns, but higher leverage also increases equity risk and expected distress costs.

The amount of leverage a project can achieve (or the level of debt that can be raised) depends on the project's profitability (the greater the level of income that can be contractually assured, the greater the amount of debt a project can support), the nature and extent of risks, the cash flow characteristics, the lenders' cash flow cover requirements, the lenders' views on the debt-equity ratio for particular types of projects, the extent of credit support mechanism, the loan parameters (interest rate, maturity, loan amortization), the security arrangements, the creditworthiness of the parties involved, and the industrial sector to which the project belongs. The terms of the debt and equity are tailored to the characteristics of the project. High leverage in project finance improves the return on equity because it takes advantage of the fact that debt is cheaper than equity (Shah \& Thakor, 1987). Lenders are willing to accept a lower return (for their lower risk) than an equity investor. In addition, tax benefits may make high leverage more attractive because interest is tax deductible, whereas dividends are not (Yescombe, 2002). To assess the projected ability to service debt (interest payments and principal repayments), lenders calculate margins of safety or coverage ratios (note 2).

\section{d. Liquidity of Project Bond Market}

The bond market is typically restricted to banks and institutional investors (pension funds, infrastructure funds, insurance companies) who are willing to do long-term investments. The lack of a bond market infrastructure, and a secondary market for pricing and liquidity reduces the attractiveness of the investment for some investors and require higher interest rates. But this problem is not as great as it at first appears because many project bonds are placed on a private basis (private placement), to investors who do not intend to trade them in the market (Yescombe, 2002). In addition, investment banks may maintain a liquid market by trading in the project bond.

\section{e. Investors' Attitude to Finance Long-Term Project in the Energy Industry}

Issuing bonds has to take into account two major problems: risks involved and the long-term nature of the project. Investing in energy projects requires a long-term perspective, due to the time horizon of projects realization. Such projects usually express their potential returns only after several years. Energy infrastructure projects seem good long-term assets with high public importance (Brealey, Cooper, \& Habib, 1996). Large long-term institutional investors (in particular insurance companies and pension funds) are potential buyers of financial instruments for initiatives in project financing. They may represent huge players in financing energy investments. Long-term 
investors are characterized by a low reliance on short-term market liquidity, due to stable resources. They require a good long-term fixed-rate return without taking equity risk. The main characteristics of long-term investors should be: the ability to retain assets longer than other market players; the ability to invest in assets that yield a profitable return in the long-run; the availability of long-term liabilities in the balance sheet.

\section{f. Project Size}

The bond market represents an efficient means of financing a large project because of the high transaction costs and scale economies. Financing energy projects with project bonds may be a successful strategy when the project is large and capable of standing alone as an independent economic unit. Structuring and issuing bond projects involves high costs of transactions: costs of screening, evaluating, selection and monitoring the project, costs of obtaining information, costs of determining and implementing the financial arrangements, costs of organizing the placement (private or public) of bond issues in the capital markets with institutional investors, costs of monitoring and controlling the bond issuer, costs of providing information to capital markets. Project bond-based financing structure requires significantly high transaction costs, that result also from capital market imperfections (agency conflicts, asymmetric information, bounded rationality, opportunistic behavior, etc.). The higher the transaction costs the higher the size of the project to be profitable and financially suitable for the bond markets. The biggest drawback of bond-based financing is that it is considered inefficient for small transactions. Consequently, project bonds tend to involve large projects.

\section{Funding Project Finance in the Energy Industry: The Project Bond Market and the Credit Support Provided by the European Investment Bank (EIB) and the European Union (EU)}

The financing of large-scale projects through bank debts has become more difficult because since the financial crisis, the capital and liquidity requirements for commercial banks have become much stricter. Basel 2 and 3 have put pressures on banks' balance sheets (Basel 2 and 3 impact on bank lending), while public budgets remain constrained. The tighter capital standards that are imposed on commercial banks have significantly reduced the available long term funding for projects in the energy industry. In addition, legal lending constraints with regard to loans to a single borrower and risk management guidelines can limit the availability of long-term funds to finance large projects in the energy industry. The latter can incentive banks to finance large projects through loan syndication.

The banking sector will not be able to provide alone the amounts of debt that are required by large-scale energy projects. There is the need to find ways to mobilise private sector investors, without increasing direct public funding and public indebtedness. Identifying alternative long-term debt sources is critical in terms of available amounts for energy projects. With the "Europe 2020 Project Bond Initiative" the European Commission promotes credit support (payment guarantees or credits) provided by the European Investment Bank. The European financial support aims to assure long-term financing for European infrastructures against the background of increasingly limited public funding, and growing constraints on long term bank lending. The European initiative does not aim at substituting bank financing, but at ensuring compatibility.

The proposed financial support from the European Investment Bank and the European Union could take the form of a debt service guarantee or an additional layer of debt at the subordinated level. The debt service guarantee could be in the form of a contingent credit line provided to the project entity by the European Investment Bank (or another financing partner), which would inject funds into the special entity if the project were unable to generate sufficient cash in the short to medium term to service its debt for any reason (figure 1). In details, the project company issues project bonds on the capital market to finance an infrastructure project. Private investors (usually institutional investors) buy the project bonds. The project company repays the bond from its current revenues. The guarantee enters into force if and when the bond cannot be serviced from the current revenues "for any reason" (European Commission, 2011). In this case, the holders of the bond concerned are serviced by the European Investment Bank guarantee payments to the maximum of the previously determined guarantee sum.

Rather than issuing a permanent guarantee, the European Investment Bank can also issue a credit to the project company to the maximum amount of $20 \%$ of the investment sum (figure 2). The European Investment Bank's credit is an alternative to payment guarantees. A project company (special entity) would divide (tranche) its debt into two layers: a senior portion (project bond) to be placed with institutional investors, and a subordinated debt obligation, which would be underwritten by the European Investment Bank.

As described above, European Investment Bank and the European Commission support the development of project bonds, by providing credit enhancement facilities. The European Commission promotes payment guarantees (or credits) to be issued by the European Investment Bank. The European Commission sets eligibility conditions for those projects benefiting from "Project Bond Guarantee Facility". As stated in the consultation paper (European Commission, 2011), "they should be economically and technically sound and cost-effective, have stable and strong 
cash flows and have a real prospect of financial viability". The European Union needs to assess by itself the risks and financial viability of such projects.

The European Investment Bank's intervention will enhance the credit quality of the senior bonds, thus making these bonds eligible for the portfolios of institutional investors. The European Investment Bank will then partially transfer the credit risks taken on the subordinated bond on to the EU via appropriate risk sharing mechanisms. The European Union will support the "Project Bond Initiative" via risk sharing mechanisms with the European Investment Bank. Public payment guarantees or credits encourage the participation of private investors in energy industry through improved ratings. Most energy projects (particularly in the renewable energy sector) have high up-front capital costs relative to competing technologies and low rates of return. These features limit the private investors' attitude to finance high risk and low return investments. The credit enhancement is a powerful instrument to boost appetite on project bonds. It can motivate banks and bond investors to lend for projects they perceive as risky. Both forms of credit enhancement (public guarantees and credits) can lead to upgrade the rating of the project. This facility is a key element in securing an investment grade rating for the project bond. This promotes insurance companies, pension funds, and infrastructure funds, to buy project bonds. The law prescribes them minimum requirements related to the rating of individual projects. On the one hand, a low credit standing of the project bonds may preclude institutional investors from purchasing bonds of a particular project. On the other hand, the investment-grade rating of the project bonds (AAA) is eligible to most institutional investors. By upgrading a rating to "investment-grade", public guarantees (or credits) can promote the subscription of project bonds and thus encourage the participation of private investors. The enhancement of the credit rating of project bonds increases the attractiveness of long-term investment to private sector participants.

The acquisition of project bonds bears a high risk for private investors. The certain high investment costs are faced with uncertain current revenues. The risk is reduced if a part of the current revenues is insured by payment guarantees. This leads to an improved rating of project bonds and gives the chance to raise funds in the bond market at low interest rates (reducing borrowing costs). The need for credit enhancement will depend on the characteristics, risks and opportunities of each project as well as on the financial situation of the project company. The credit enhancement will be useful to both accelerate financial close of bankable projects, and to make bankable other projects.

The proposed European financial support for the development of the project bond market gives the European Union and the European Investment Bank a particular role:

- The European Investment Bank will help develop a pipeline of private-public partnership projects on the basis of a clearly defined eligibility framework. The European Investment Bank should assess the project pipeline in order to identify potential candidates for project bonds;

- The European Investment Bank will carry out the due diligence and financial appraisal in the structuring phase, price the guarantee or loan and monitor the project. The European Investment Bank will assess in detail all projects to determine the robustness of their financing structure, as it has the appropriate expertise. Potential investors may not have the expertise to appraise projects and carry out the analytical and administrative evaluation;

- The European Union and the European Investment Bank would share the risk of the losses of the project portfolio. The maximum amount of the default risk borne by the European Union is limited to the reserves of the EU financial framework, retained especially for such cases;

- The European Investment Bank will be the controlling creditor (bond creditors' representative): it takes responsibility for monitoring the project implementation and negotiates with the project company on behalf of all bondholders in case of need.

The credit support provided by the European Investment Bank will likely promote the bond-based financing structure in the project finance market. It will create an asset class attractive to investors and help raise capital to finance long-term investments and large scale energy projects that contribute to lung-run economic growth. Nevertheless, many microeconomic and macroeconomic issues are on the ground. There is a strong interaction between financial regulation and economic effects of new debt-based funding models in project finance. Stricter bank capital regulations forced many banks to reduce the availability of bank funding for large projects. The impact of Basel 3 is likely to be negative, particularly in Europe. It will have a huge impact on bank lending. It may reduce liquidity to invest in the project finance sector. As a result of the subprime lending crisis and the resulting credit crunch, and as a consequence of the debt crisis of many EU States, project bonds could become more attractive to private investors since payment defaults can no longer be excluded for sovereign bonds. The development of a project bond market has a positive impact on public debt sustainability. 
In this perspective of analysis, a key question could be how to structure project bonds in order to attract demand from long-term investors. In order to be a successful financial instrument, the project bond should gather the following characteristics:

1. Attracting high quality sponsors: project bonds represent a financing alternative and offer liquidity although it must compete with traditional bank loans;

2. Attracting credit enhancement tools to produce the required ratings suitable for bond investor demand. A strong investment-grade credit rating of the project bonds might be the way to convince long-term investors to participate in large energy projects;

3. Involving institutional investors to match long-term liabilities with long-term projects: investment-grade rating grants the access of institutional investors;

4. Involving high quality projects: well structured projects with high quality cash flows and financial robustness allow to achieve investment grade rating. The repayment of project debt is totally dependent upon project cash flows;

5. Involving an independent asset manager to provide monitoring, surveillance and reporting to bond investors;

6. Involving best practices in financial engineering that may be used to enhance project attractiveness to potential investors and develop multiple financing structures to attract various investors to projects (note 3 ).

More broadly, the above analyses highlight the fact that the effectiveness of project bonds, as financial instruments, is strictly related not only to the efficiency and well-functioning of the primary capital market but also to the secondary one. Based on this point, some policy implications can be suggested for the development of a bond-based financing structure in the energy industry:

- Creating a capital market infrastructure for the European project bonds (placement, listing, trading, and settlement procedures). The European Investment Bank may create a trading platform to improve liquidity and pricing, provide liquidity in the project bond market, provide a facility to purchase unsold project bonds (these could then subsequently be sold in the financial market);

- Encouraging private investments by providing a supportive investor regulation. A new regulatory framework, more friendly with long-term investments, should involve accounting standards, prudential principles, corporate governance, and fiscal incentives (note 4);

- Encouraging expertise to manage complex project finance transactions. In a pilot phase, it may be useful to undertake economic and financial analyses in order to collect good practices, exchange knowledge and methodological supports;

- Evaluating the potential effects of the new banking regulation (Basel 3) on project bond market (possible distortions are due to the treatment of project debt in capital requirement measures).

- Promoting the creation of an international special purpose vehicle (SPV) to issue project bonds for cross-border energy projects;

- Promoting the harmonization of national regulation and legal frameworks that help structure different financial schemes of project bonds and develop innovative financial instruments tailored to the energy sector;

- Providing information on the opportunities in investing in project bonds related to projects in the energy industry;

- Building effective financing partnerships with the private sector. Most energy projects, renewable energy projects in particular, rely on government and public funding.

Nevertheless, as a final point, it is worth noting that some aspects of the "Europe 2020 project bond initiative" may raise critical issues:

1. The availability of the guarantee facility is related to European Investment Bank's assessment criteria. Underlying projects need to satisfy EIB's assessment criteria (projects must be technically robust and financially sound);

2. The credit enhancement can be used only for some energy projects (selected by the European Investment Bank). This affects the bankable projects and the possibilities to raise private capital in the debt capital market. Is also creates a possible distortion of competition among bond issuers;

3. The European Investment Bank may involve bureaucratic procedures to assess projects which could be time consuming; 
4. The role of European Investment Bank's controlling creditor may be controversial. Bond investors will likely not accept the European Investment Bank acting as sole controlling creditor. In addition, bond investors may require voting rights with regard to "events of default".

In brief, the European Investment Bank could become an "enabler" to promote the development of the project bond market and encourage private-sector participation in the financing of energy projects. The European Investment Bank will screen, assess, mitigate and monitor project risk as an experienced player, and will provide guarantees/sub-debt to obtain ratings uplift.

\section{Conclusion}

The paper highlights several important characteristics of the project bond market. The project bond, as an innovative financial instrument, is a useful tool by helping to bring private and public funds together to finance projects of major public interest. Project bonds can attract capital market financing for long-term energy infrastructure projects. Project finance is likely to be increasingly important in the future as European countries rely on it to develop their energy infrastructures. It can provide funding for investments in the energy industry that the public sector might not be able to undertake.

For the near future we can expect the development of expertise, lending and private placement capabilities to lower size threshold to access bond market to fund projects in the energy industry. The exchange of best practices between European countries would be very helpful in this field. There is also increasing investors' interest in debt funds investing in energy infrastructures. New funding structures will be developed to meet the needs of the project finance market and balance the needs of investors with the needs of the public sector.

\section{References}

Bassanini, F., \& Reviglio, E. (2011). Financial Stability, Fiscal Consolidation and Long-term Investment after the Crisis. OECD Journal: Financial Market Trends. 21 (1). http://dx.doi.org/10.1787/fmt-2011-5kg55qw1vbjl.

Beidleman, C. R., Fletcher, D., \& Veshosky, D. (1990). On allocating risk: the essence of project finance. Sloan Management Review, 31 (3).

Brealey, R. A., Cooper, I. A., \& Habib, M. A. (1996). Using Project Finance to Fund Infrastructure Investments. Journal of Applied Corporate Finance, 9. http://dx.doi.org/10.1111/j.1745-6622.1996.tb00296.x.

Buljevich, E. C., \& Park, Y. S. (1999). Project Financing and the International Financial Markets. Norwell, MA: Kluwer Academic Publishers.

Dailami, M., \& Hauswald, R. (2003). The Emerging Project Bond Market: Covenant Provisions and Credit Spreads. World Bank Policy Research, Working Paper n. 3095.

Esty, B. C. (2004a). Why Study Large Projects? An Introduction to Research in Project Finance. European Financial Management, 10. http://dx.doi.org/10.1111/j.1354-7798.2004.00247.x.

Esty, B. C. (2004b). Modern Project Finance: A Casebook, New Jersey: John Wiley \& Sons.

Esty, B. C. (2003). The Economic Motivations for Using Project Finance, Harvard Business School, Working Paper.

Esty, B. C. (2002). Returns on Project-Financed Investments: Evolution and Managerial Implications. Journal of Applied Corporate Finance, 15. http://dx.doi.org/10.1111/j.1745-6622.2002.tb00342.x.

European Commission. (2011). Europe 2020 Project Bond Initiative, February.

Fabozzi, F., \& Nevitt, P. (2000). Project Financing, London: Euromoney Books.

Farrell, L. M. (2003). Principal-agency risk in project finance. International Journal of Project Management, 21. http://dx.doi.org/10.1016/S0263-7863(02)00086-8.

Finnerty, J. D. (2007). Project Financing. Asset-Based Financial Engineering, New Jersey: John Wiley \& Sons.

Gatti, S. (2008). Project Finance in Theory and Practice. Burlington Academic: Press.

John, T. A., \& John, K. (1991). Optimality of Project Financing: Theory and Empirical Implications in Finance and Accounting. Review of Quantitative Finance and Accounting, 1. http://dx.doi.org/10.1007/BF02408406.

Khan, M. F. K., \& Parra, R. J. (2003). Financing Large Projects: Using Project Finance Techniques and Practises. Essex: Pearson Education.

Kleimeier, S., \& Megginson, L. W. (2000). Are project finance loans different from other syndicated credits? Journal of Applied Corporate Finance, 12. http://dx.doi.org/10.1111/j.1745-6622.2000.tb00043.x. 
Myers, S. C., \& Majluf, N. S. (1984). Corporate financing and investment decisions when firms have information that investors do not have, Journal of Financial Economics. 13. http://dx.doi.org/10.1016/0304-405X(84)90023-0.

Shah, S., \& Thakor, A. V. (1987). Optimal Capital Structure and Project Financing. Journal of Economic of Theory, 42. http://dx.doi.org/10.1016/0022-0531(87)90086-X.

Yescombe, E. R. (2002). Principles of Project Finance, San Diego: Academic Press.

Wynant, L. (1980). Essential Elements of Project Financing. Harvard Business Review, 58 (3).

\section{Notes}

Note 1. Covenant provisions contained in bond typically take the form of restrictions on dividend, M\&A transactions, and asset disposals, limitations on indebtedness, requirements of third party guarantees, maintenance of good regulatory standing and, in certain circumstances, the establishment of offshore and debt service reserve accounts (Dailami \& Hauswald, 2003, p. 8).

Note 2. The main ratios to measure project capacity to face debt obligations are: Debt Service Coverage Ratio $(\mathrm{DSCR})=$ Cash Flow available for debt service/Debt service (principal, interest and commissions); Interest Coverage Ratio $(\mathrm{ICR})=$ Cash Flow available for debt service/Interest; Loan Life Coverage Ratio (LLCR) = NPV of Cash Flows available for debt service (during debt) discounted at debt rate/Outstanding debt.

Note 3. For example, aggregating several project finance deals in one portfolio (to diversify risks) and issuing project-based bonds. In this way, investors may insure themselves against possible payment defaults distributing their private capital among various projects. Nevertheless, the diversification of the portfolio of projects is not always possible because in different sectors (such as transport, energy and communications) there might be high correlations.

Note 4. The mark-to-market accounting rule is particularly damaging for long term investments, attributing instant market values to assets the value of which is based on a long-term perspective. Accounting frameworks should encourage long-term investments with positive effects for financial market stability. See Bassanini \& Reviglio (2011).

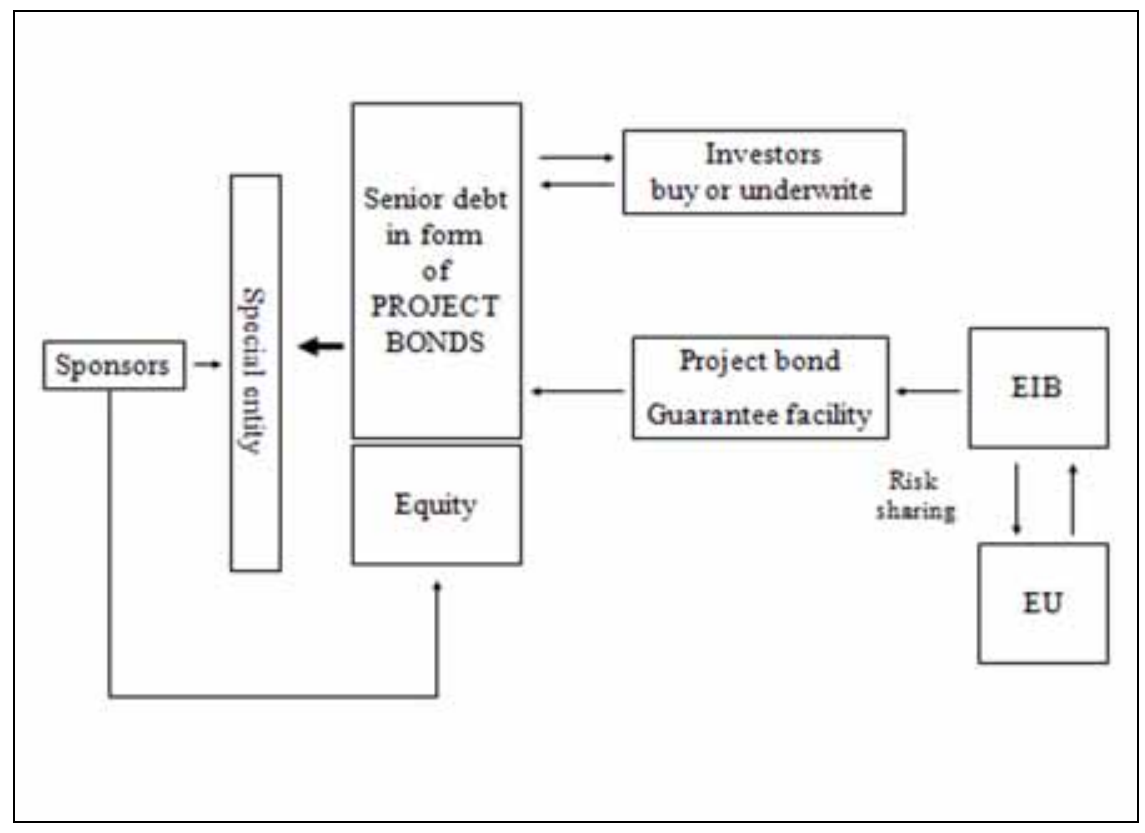

Figure 1. The European Financial Guarantee

Project finance: bond-based financing model and European financial facility (guarantee). The EIB grants a payment guarantee covering the entire term of the project bond.

Source: European Commission (2011). 


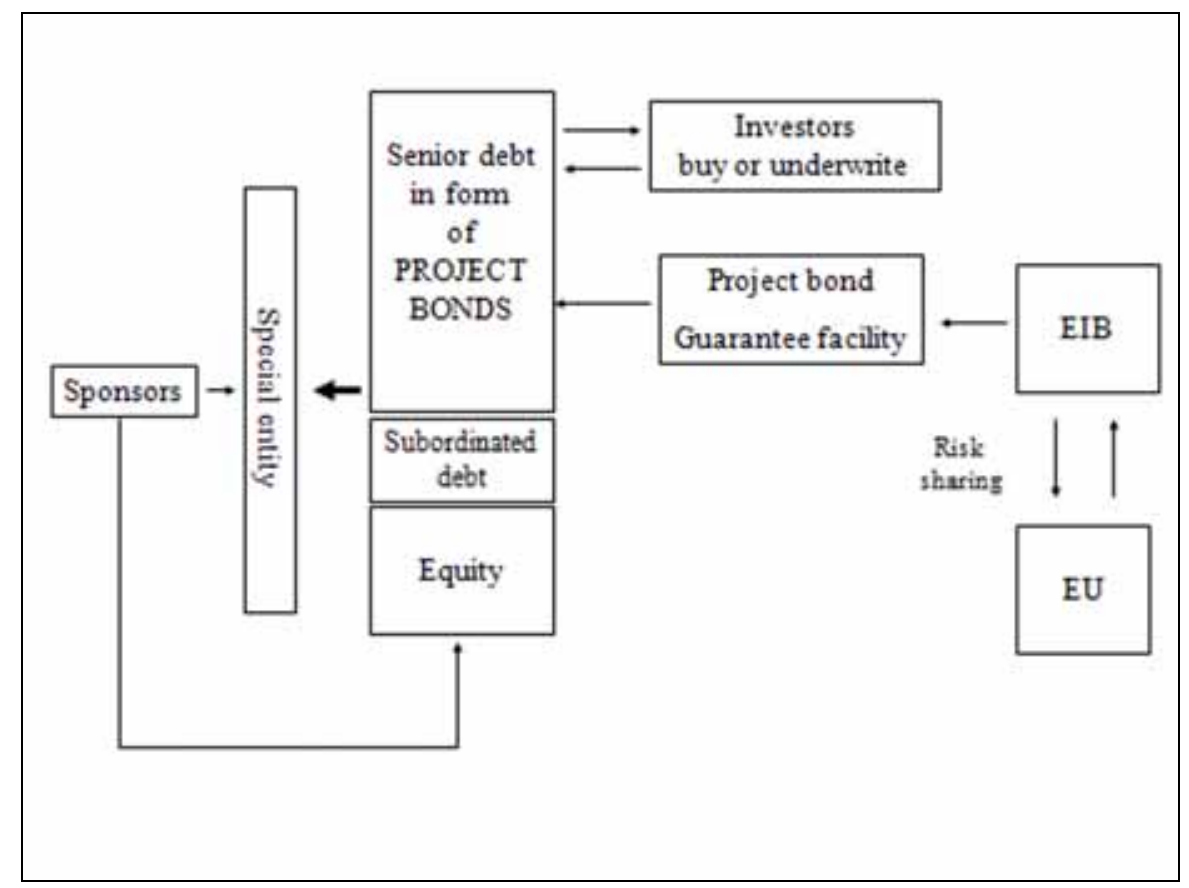

Figure 2. The European Subordinated Debt

Project finance: bond-based financing model and European financial facility (subordinated debt). The EIB issues a credit to the project company. Source: European Commission (2011). 